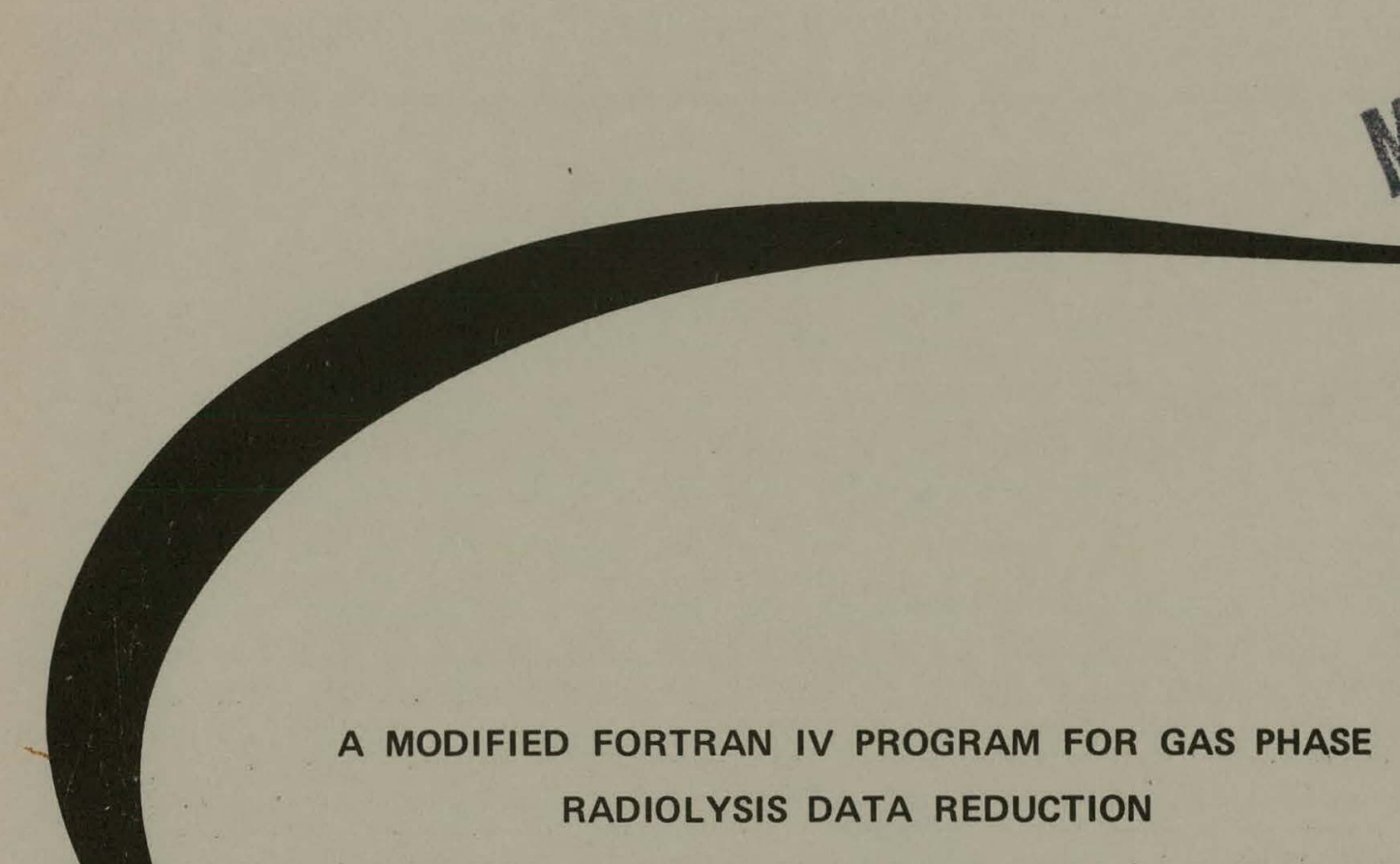

\author{
George J. Werkema

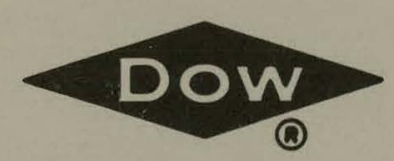 \\ THE DOW CHEMICAL COMPANY \\ ROCKY FLATS DIVISION \\ P. O. BOX 888 \\ GOLDEN, COLORADO 80401 \\ U.S. ATOMIC ENERGY COMMISSION \\ CONTRACT AT(29-1)-1106
}




\section{DISCLAIMER}

This report was prepared as an account of work sponsored by an agency of the United States Government. Neither the United States Government nor any agency Thereof, nor any of their employees, makes any warranty, express or implied, or assumes any legal liability or responsibility for the accuracy, completeness, or usefulness of any information, apparatus, product, or process disclosed, or represents that its use would not infringe privately owned rights. Reference herein to any specific commercial product, process, or service by trade name, trademark, manufacturer, or otherwise does not necessarily constitute or imply its endorsement, recommendation, or favoring by the United States Government or any agency thereof. The views and opinions of authors expressed herein do not necessarily state or reflect those of the United States Government or any agency thereof. 


\section{DISCLAIMER}

Portions of this document may be illegible in electronic image products. Images are produced from the best available original document. 


\section{LEGAL NOTICE}

This report was prepared as an account of Government sponsored work. Neither the United States, nor the Atomic Energy Commission, nor any person acting on behalf of the Commission:

A. Makes any warranty or representation, expressed or implied, with respect to the accuracy, completeness, or usefulness of the information contained in this report, or that the use of any information, apparatus, method, or process disclosed in this report may not infringe privately owned rights; or

B. Assumes any liabilities with respect to the use of, or for damages resulting from the use of any information, apparatus, method, or process disclosed in this report.

As used in the above, "person acting on behalf of the Commission" includes any employee or contractor of the Commission, or employee of such contractor, to the extent that such employee or contractor of the Commission, or employee of such contractor prepares, disseminates, or provides access to, any information pursuant to his employment or contract with the Commission, or his employment with such contractor.

Printed in the United States of America

Available from

Clearinghouse for Federal Scientific and Technical Information

National Bureau of Standards, U. S. Department of Commerce

Springfield, Virginia 22151

Price: Printed Copy $\$ 3.00 ;$ Microfiche $\$ 0.65$ 
RFP-1404

UC-4 CHEMISTRY

TID-4500 - 54th Ed.

\title{
A MODIFIED FORTRAN IV PROGRAM FOR GAS PHASE RADIOLYSIS DATA REDUCTION
}

\author{
George J. Werkema
}

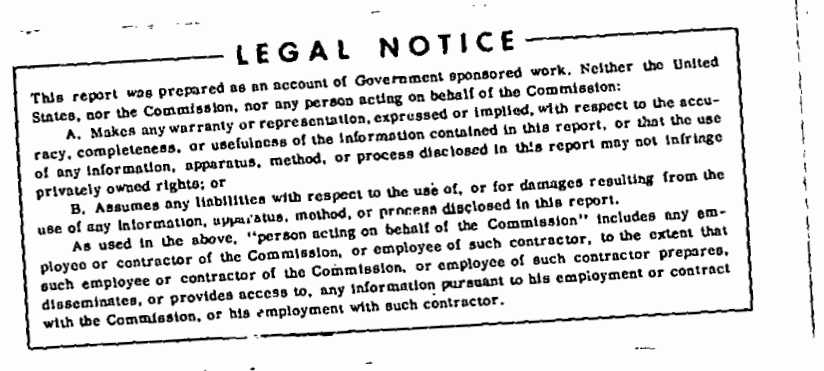

\footnotetext{
THE DOW CHEMICAL COMPANY ROCKY FLATS DIVISION

P. O. BOX 888

GOLDEN, COLORADO 80401

Prepared under Contract AT(29-1)-1106

$$
\text { for the }
$$

Albuquerque Operations Offire

U. S. Atomic Energy Commission
} 
RFP-1404 


\section{CONTENTS}

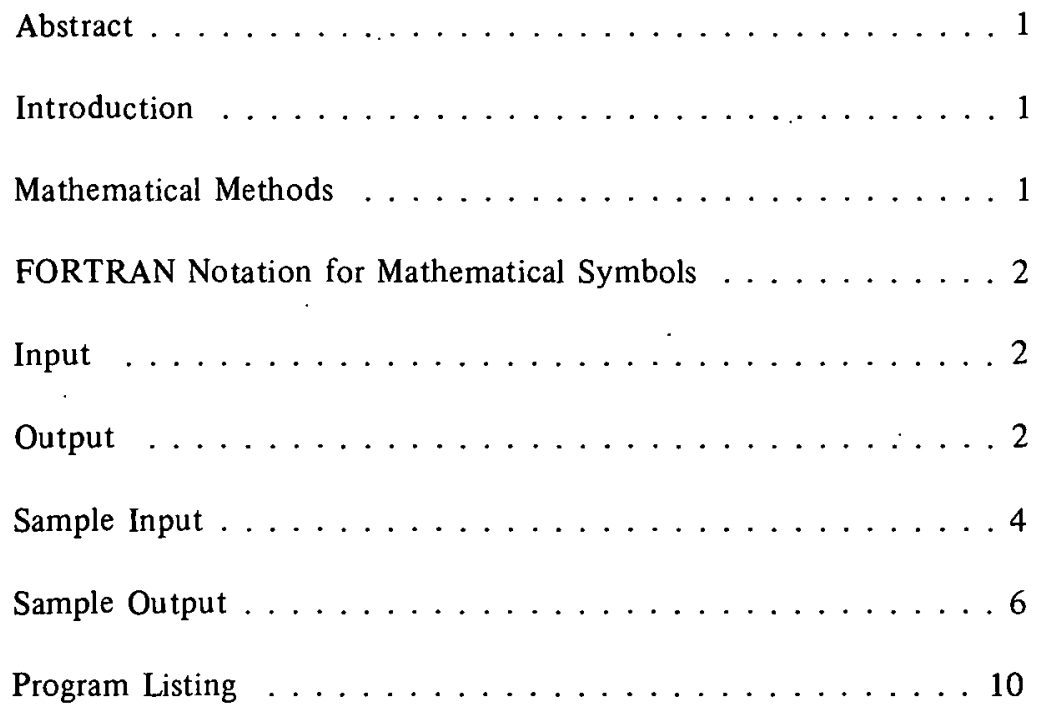


RFP.1404 


\title{
A MODIFIED FORTRAN IV PROGRAM FOR GAS PHASE RADIOLYSIS DATA REDUCTION
}

\author{
George J. Werkema
}

\begin{abstract}
This program is a modification of one written earlier (USAEC Report RFP-624, Rocky Flats Division, The Dow Chemical Co., November 1965) for a small computer. The availability of a computer having a medium-to-large memory permits various improvements to be made in operating convenience. The present version, RADF-2, is written in E-level FORTRAN IV for the IBM 360/40G computer. The RADF-2 program converts analytical data obtained at several times during a gas phase radiolysis experiment into the molar and molecular quantities which may be plotted or further reduced to "G" values. The computed results are output in tabular form for each gas, along with the computed radiation dose, as a function of time.
\end{abstract}

\section{INTRODUCTION}

Although the algorithm for the reduction of gas analysis data is trivial, it is a tedious and time-consuming exercise, and is quite subject to errors. For accurate work, accounting for the small amounts of gas that are removed with each sampling increases the complexity of the arithmetic. The RADF* computer code, and the present modification, RADF-2, were written to reduce analytical data arising from gas phase radiolysis experiments.

This computer code implies few experimental qualifications. It is assumed that the radiolytic reaction takes place in a constant, sealed volume, and that small samples of the gaseous reaction mixture are periodically withdrawn for analysis. The results of the chemical analysis are dimensioned in volume percentages of each gas, which are input to the RADF-2 program. For chemical kinetics studies, it is necessary to know the total quantity of each gas present at cach sampling time, which is equal to the measured quantity at each time plus the amount of each gas removed in all previous samplings. RADF-2 provides this sample accounting feature, and all calculated gas quantities are the sum of the current quantity plus the past sample quantities for cach gas.

It is also useful to know the amount of radiation to which the reaction mixture has been exposed at each

\footnotetext{
*RADF - Abbreviation for RADiolysis Fortran.
}

sampling period. RADF-2 computes radiation dose as a function of elapsed time for each sampling. The user may choose between two dose calculation options. One option is based on an exponential source decay, and the other assumes a constant dose rate.

\section{MATHEMATICAL METHODS}

The total number of moles of all gases in the reaction vessel at some time $\left(\mathrm{t}_{\mathrm{j}}\right)$ is computed using the equation of state of an ideal gas:

$$
n_{j}=\frac{P_{j} V}{R T_{j}} .
$$

The number of moles of each gas $\left(n_{j, i}\right)$ is computed from the expression

$$
n_{j, i}=n_{j} \cdot\left(\frac{V_{i}}{V}\right)_{j},
$$

where $\left(\frac{V_{i}}{V}\right)_{j}$ is the volume fraction of gas (i) in the reaction at some time $\left(t_{j}\right)$. Next, the number of moles of each gas $\left(\mathrm{S}_{\mathrm{j}, \mathrm{i}}\right)$ in the sample volume $\left(\mathrm{V}_{\mathrm{S}}\right)$ is given by

$$
S_{j, i}=n_{j, i} \cdot \frac{V_{s}}{V} .
$$

Finally, the total number of moles of each gas $\left(\mathrm{N}_{\mathrm{j}, \mathrm{i}}\right)$ is:

$$
\mathrm{N}_{\mathrm{j}, \mathrm{i}}=\mathrm{n}_{\mathrm{j}, \mathrm{i}}+\sum_{\mathrm{i}}^{\mathrm{j}} \mathrm{s}_{\mathrm{j}, \mathrm{i}} \cdot
$$

The number of molecules of each gas $\left(\mathrm{M}_{\mathrm{j}, \mathrm{i}}\right)$ is obtained by multiplying $\mathrm{N}_{\mathrm{j}, \mathrm{i}}$ by Avogadro's number. The change in molecular population from zero time is given by

$$
\Delta \mathrm{M}_{\mathrm{j}, \mathrm{i}}=\mathrm{M}_{\mathrm{j}, \mathrm{i}}-\mathrm{M}_{1, \mathrm{i}}
$$

where $M_{1, i}$ is the initial population of gas (i).

The computation of accumulated radiation dose is similarly direct. For an exponentially decaying source, the dose accumulated at some time $\left(\mathrm{t}_{\mathrm{j}}\right)$ is given by

$$
(\operatorname{DOSE})_{j}=\frac{A_{0} \bar{E}}{\lambda} \cdot C\left[1-\exp \left(-\lambda t_{j}\right)\right] \text {, }
$$


where

$$
\begin{aligned}
& A_{0}=\begin{array}{l}
\text { activity of source at the start of the } \\
\text { experiment (curies), }
\end{array} \\
& \bar{E}=\text { average energy of source emission }(\mathrm{MeV}), \\
& \lambda=\begin{array}{l}
\text { decay constant for source }=\log _{\mathrm{e}} 2 / \mathrm{t}_{1 / 2} \\
\left(\mathrm{hr}^{-1}\right),
\end{array} \\
& \mathrm{t}_{\mathrm{j}}=\quad \begin{array}{l}
\text { elapsed time from the beginning of the } \\
\mathrm{C}=
\end{array} \\
& \begin{array}{l}
1.332 \mathrm{xperiment} 10^{20} \text { which is an internal constant } \\
\text { used to dimension DOSE in electron volts. }
\end{array}
\end{aligned}
$$

Alternatively, the value of (DOSE); when a constant artivity source is used is simply the product of the suurce activity and time $\left(t_{j}\right)$. The dose rate for a constant. activity source is input to the program in the $\lambda$ data field. Blank data fields for $A_{O}$ and $\bar{E}$ signal the program to use the constant source routine for the calculation of (DOSE) $)_{j}$

The program calls one special library subroutine, $\operatorname{EXP}(a)$. This is normally available in most FORTRAN compiler libraries.

\section{FORTRAN NOTATION FOR MATHEMATICAL SYMBOLS}

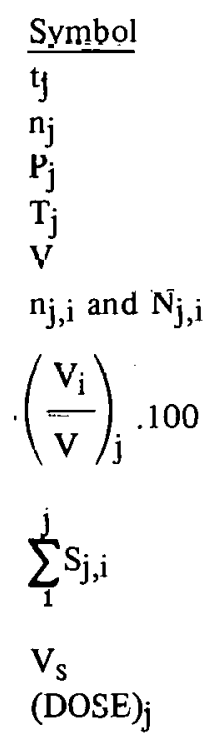

$\mathrm{A}_{\mathrm{O}}$

$\bar{E}$

$\lambda$

number of gases, $1 \leqslant i \leqslant k$

FORTRAN Label
TIMP, (J)
ALL
P
T
V

GASMOL (J,I)

r.ASVP (I)

SUMSAM (I)

SV

IDOSE (J)

AZRO

EBAR

FLAM

$\mathrm{I}, \mathrm{K}$ (I is running) number of samples, $1 \leqslant \mathrm{j} \leqslant \ell$

\begin{tabular}{|c|c|c|c|}
\hline Card & Card Column & Data Required & Format \\
\hline 1 & $5-8$ & $\begin{array}{l}\text { Number of experiments } \\
\text { to be run }\end{array}$ & $\overline{14}$ \\
\hline 2 & $5-68$ & $\begin{array}{l}\text { TITLE, Alphanumeric } \\
\text { information, e.g. experiment } \\
\text { identification }\end{array}$ & $\mathrm{I} 6 \mathrm{~A} 4$ \\
\hline \multirow[t]{6}{*}{3} & $11-14$ & L-number of samples & I4 \\
\hline & $15-18$ & K-number of gases & I4 \\
\hline & $19=30$ & $\begin{array}{l}\text { V-reaction vessel volume } \\
\text { (cs.) }\end{array}$ & F12.6 \\
\hline & $31-42$ & $\mathrm{~A}_{\mathrm{o}}$ (curies) & F12.6 \\
\hline & 43.54 & $\overline{\mathrm{E}}(\mathrm{MeV})$ & F12.6 \\
\hline & $55-64$ & $\begin{array}{l}\lambda\left(\mathrm{hr}^{-1}\right) \text { Alternatively, the } \\
\lambda \text { data field may be used to } \\
\text { input the dose rate for a } \\
\text { constant activity source if } \\
\text { the } A_{o} \text { and } \bar{E} \text { data fields are } b\end{array}$ & lank. \\
\hline \multirow[t]{4}{*}{4} & $13-22$ & $\begin{array}{l}P_{j}-\text { reaction pressure at } \\
\text { time of sampling }(\mathrm{mm} . \mathrm{Hg})\end{array}$ & F10.4 \\
\hline & $23-32$ & $\begin{array}{l}\mathrm{T}_{\mathrm{j}} \text { - temperature at time of } \\
\text { sampling (deg. } \mathrm{C} \text { ) }\end{array}$ & F10.4 \\
\hline & $33-42$ & $V_{S}$ - sample volume (cc.) & F10.4 \\
\hline & $43-52$ & $\begin{array}{l}\mathrm{t}_{\mathrm{j}} \text { - elapsed time at which } \\
\text { sample is taken (hrs.) }\end{array}$ & F10.4 \\
\hline $5,6,7, \ldots$ & $13-20$ & Gas Formula & $2 . \mathrm{A} 4$ \\
\hline $\begin{array}{l}\text { etc. for } \\
\text { each of } \mathbf{K} \\
\text { gases in } \\
\text { sample }\end{array}$ & 21.28 & Gas Volume percent & F8.4 \\
\hline
\end{tabular}

$\mathrm{M}_{\mathrm{j}, \mathrm{i}}$

$\Delta \mathrm{M}_{\mathrm{j}, \mathrm{i}}$

number of experiments

$\mathrm{J}, \mathrm{L}(\mathrm{J}$ is running)

AVOGAS $(\mathrm{J}, \mathrm{l})$

$\operatorname{DELMCL}(\mathrm{J}, \mathrm{I})$

NJOB

\section{INPUT}

Preparc one set of oards $4,5,6,7$. for each of the $L$ samples. The total number of cards to be prepared is thus

$$
3+\left(1+K_{n}\right) \cdot \mathbf{L}
$$

The romposition of a deck to process data from several experiment3 is illustrated in Figure 1. The sequence of gas formulae and data cards must be constant for all sample sets in one expeirment.

\section{OUTPUT}

RADF-2 generates three tables of output. The identifying characters, "RAD", are printed at the top of the first 
page. Each table is headed by a verbatim listing of the information in the TITLE input field. The first table lists micromolar quantities of each analyzed gas in the sample; the second table lists the number of molecules of the sample gases; and the third table lists the change in molecular population from zero time. Column headings across the top of each table indicate TIME $\left(=t_{j}\right)$, DOSE $=(D O S E)_{j}$, and the formulae for the analyzed gases. A sample of the output tables for ten gases analyzed six different times is shown on pages 7-9. 


\section{RFP-1404}

Figure 1. Sample Input

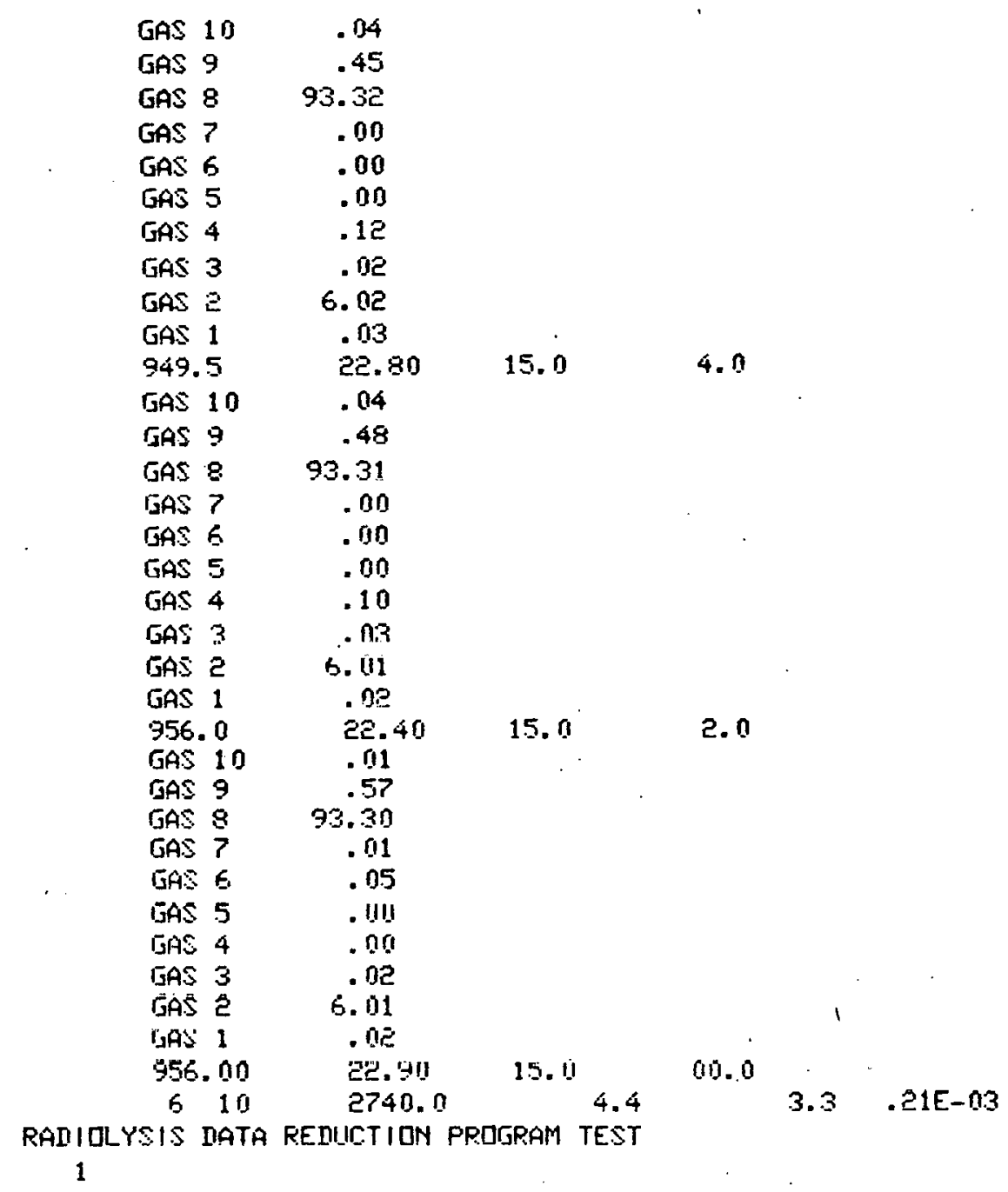

00000000000000000000000000000000000000000000000000000000000000000000000000000000

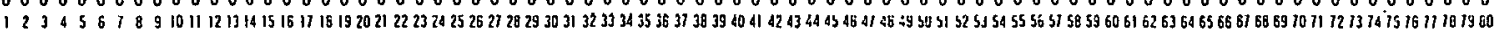
111111111111111111111111111111111111111111111111111111111111111111111111111

22222222222222222222222222222222222222222222222222222222222222222222222222222222

33333333333333333333333333333333333333333333333333333333333333333333333333333333

4444444444444444444444444444444444444444444444444444444444444444444444444444444

55555555555555555555555555555555555555555555555555555555555555555555555555555555

66666666666666606666666666666606666666666666666666666666666666666666666666666666

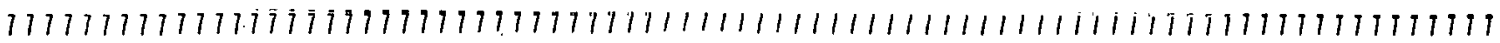

88888888888888888888888888888888888888888888888888888888888888888888888888888888

999999999999999999999999999999999999 y y y y y y y y 9 y 9999999999999999999999999999999

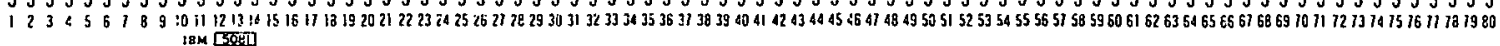


Figure 1. (cont.)

\begin{tabular}{|c|c|c|c|}
\hline GAS 10 & .06 & & \\
\hline GAS 9 & .38 & & \\
\hline GAS 8 & 93.23 & & \\
\hline GAS ? & . ne & & \\
\hline DAS 6 & .07 & & \\
\hline GAS 5 & .00 & & \\
\hline GAS 4 & .11 & & \\
\hline GAS 3 & .03. & & \\
\hline GAS 2 & 6.07 & & \\
\hline GAS 1 & $.0 \mathrm{e}$ & & \\
\hline 931.0 & 23.00 & 15.0 & 10.5 \\
\hline taS 10 & $n 6$ & & \\
\hline TAS 9 & .40 & & \\
\hline GAS 8 & 93.33 & & \\
\hline GAS 7 & . & & \\
\hline$G A S 6$ & .00 & & \\
\hline GAS 5 & .00 & & \\
\hline GAS 4 & .12 & & \\
\hline GAS 3 & .02 & & \\
\hline GAS 2 & 6.04 & & \\
\hline GAS 1 & 03 & & \\
\hline $\begin{array}{l}936.5 \\
60510\end{array}$ & 22.80 & 15.0 & 8.0 \\
\hline $\begin{array}{l}\text { LAS } 10 \\
\text { GAS } 9\end{array}$ & .05 & & \\
\hline GAS 8 & 93.20 & & \\
\hline उ月? ? & .00 & & \\
\hline JAS & .90 & & \\
\hline $575 \overline{3}$ & .00 & & \\
\hline 74 & .14 & & \\
\hline GAS 3 & .02 & & \\
\hline GAS 2 & 6.0 .5 & & \\
\hline -3AS & .02 & & \\
\hline 342.5 & 23.70 & 15.0 & 6.0 \\
\hline
\end{tabular}

00000000000000000000000000000000000000000000000000000000000000000000000000000

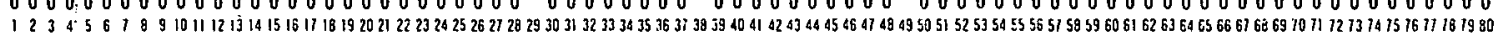
$11111 \mathrm{i} 111111111111111111111111111111111111111111111111111111111111111111111111$

$22222222222222 \quad 222222222 \quad 222222222222222222222222222222222222222222222222222222$ $333333333333333 \quad 3333333333333333333 \quad 333333333333333333333333333333333333333333$ 4444444444444444444444444444444444444444444444444444444444444444444444444444444 $5555555555555555555555555555555555 \quad 55555555555555555555555555555555555555555555$ 66666666666666665666666666666666666666666666666666666666666666666666666666666666 177777777777777777777777777777777777777777777777777777777777777777777777 88888888888888888888888888888898888888888888888888888888888888888888888888688888 99999999999999999999999999999999999999999999999999999999999999999999999999999999

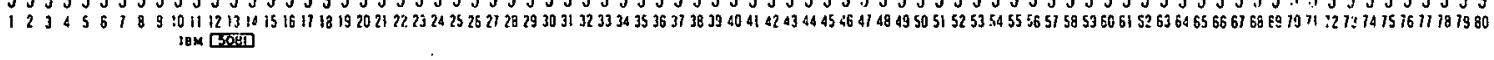


RFP-1404 
RAD

RADIOLYSIS DATA REDUCTION PROGRAM TEST

MICROMOLES OF GASES IN REACTION MIXTURE

\begin{tabular}{|c|c|c|c|c|c|c|c|c|c|c|c|c|c|c|c|c|c|}
\hline $\begin{array}{l}\text { TIME } \\
0.0 \\
2.0000 \\
4.0000 \\
6.0000 \\
8.0000 \\
10.5000\end{array}$ & $\begin{array}{l}\text { DOSE } \\
0.0 \\
3.16 E \\
5.23 E \\
6.60 E \\
7.49 E \\
8.19 E\end{array}$ & $\begin{array}{ll}2 & 1 \\
2 & 1 \\
2 & 1 \\
2 & 1 \\
2 & 1\end{array}$ & $\begin{array}{l}\text { GAS I } \\
2.84 \mathrm{E} \\
2.86 \mathrm{E} \\
4.27 \mathrm{E} \\
2.85 \mathrm{E} \\
4.25 \mathrm{E} \\
2.85 \mathrm{E}\end{array}$ & $\begin{array}{l}01 \\
01 \\
01 \\
01 \\
01 \\
01\end{array}$ & $\begin{array}{l}\text { GAS } 2 \\
8.53 E \\
8.59 E \\
8.58 E \\
8.61 E \\
8.58 E \\
8.62 E\end{array}$ & $\begin{array}{l}03 \\
03 \\
03 \\
03 \\
03 \\
03\end{array}$ & $\begin{array}{l}\text { GAS } 3 \\
2.84 E \\
4.29 E \\
2.86 E \\
2.85 E \\
2.85 E \\
4.24 E\end{array}$ & $\begin{array}{l}01 \\
01 \\
01 \\
01 \\
01 \\
01\end{array}$ & $\begin{array}{l}\text { GAS } 4 \\
0.0 \\
1.43 E \\
1.71 E \\
1.99 E \\
1.71 E \\
1.56 E\end{array}$ & $\begin{array}{l}02 \\
02 \\
02 \\
02 \\
02\end{array}$ & $\begin{array}{l}\text { GAS } \\
0.0 \\
0.0 \\
0.0 \\
0.0 \\
0.0 \\
0.0\end{array}$ & $\begin{array}{l}\text { GAS } 6 \\
7.09 E \\
0.0 \\
0.0 \\
0.0 \\
0.0 \\
9.72 E\end{array}$ & 01 & $\begin{array}{l}\text { GAS } 7 \\
1.42 E \\
0.0 \\
0.0 \\
0.0 \\
0.0 \\
2.78 E\end{array}$ & 01 & $\begin{array}{l}\text { GAS } 8 \\
1.32 E \\
1.33 E \\
1.33 E \\
1.33 E \\
1.33 E \\
1.32 E\end{array}$ & $\begin{array}{l}05 \\
05 \\
05 \\
05 \\
05 \\
05\end{array}$ \\
\hline
\end{tabular}

RAD

RADIOLYSIS DATA REDUCTION PROGRAM TEST

MICROMOLES DF GASES IN REACTION MIXTURE

\begin{tabular}{lllllll} 
TIME & DOSE & GAS 9 & \multicolumn{3}{l}{ GAS 10} \\
0.0 & 0.0 & & $8.09 E$ & 02 & $1.42 E$ & 01 \\
2.0000 & $3.16 E$ & 21 & $6.86 E$ & 02 & $5.72 E$ & 01 \\
4.0000 & $5.23 E$ & 21 & $6.42 E$ & 02 & $5.70 E$ & 01 \\
6.0000 & $6.60 E$ & 21 & $5.98 E$ & 02 & $7.10 E$ & 01 \\
8.0000 & $7.49 E$ & 21 & $5.70 E$ & 02 & $8.49 E$ & 01 \\
10.5000 & $8.19 E$ & 21 & $5.41 E$ & 02 & $8.48 E$ & 01
\end{tabular}


RAD

RADIOLYSIS DATA REDUCTION PROGRAM TEST

MOLECULES OF GASES IN REACTION MIXTURE

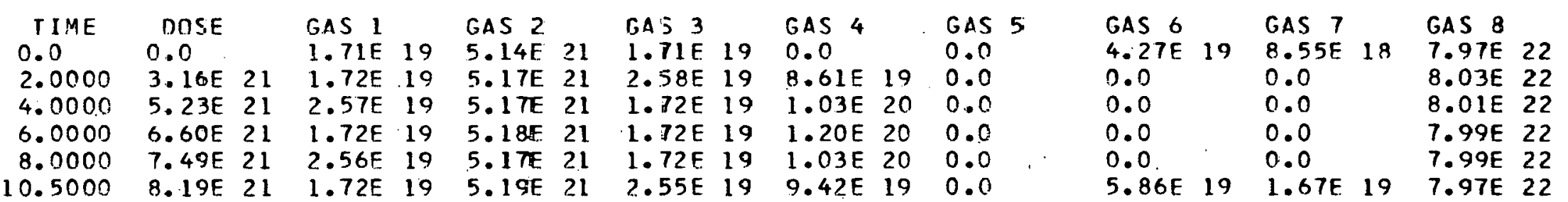

RAD

RAOIOLYSIS DATA REDUCTION PROGRAM TEST

MOLECULES OF GASES. IN REACTION MIXTURE

\begin{tabular}{lllllll} 
TIME & DDSE & GAS 9 & \multicolumn{3}{c}{ GAS 10} \\
0.0 & 0.0 & & $4.87 E$ & 20 & $8.55 E$ & 18 \\
2.0000 & $3.16 E$ & 21 & $4.13 E$ & 20 & $3.44 E$ & 19 \\
4.0000 & $5.23 E$ & 21 & $3.86 E$ & 20 & $3.43 E$ & 19 \\
6.0000 & $6.60 E$ & 21 & $3.60 E$ & 20 & $4.28 E$ & 19 \\
8.0000 & $7.49 E$ & 21 & $3.43 E$ & 20 & $5.11 E$ & 19 \\
10.5000 & $8.19 E$ & 21 & $3.26 E$ & 20 & $5.11 E$ & 19
\end{tabular}


RAD

RADIOLYSIS DATA REDUCTIDN PROGRAM TEST

CHANGE IN MOLECULE POPULATION FROM ZFRO TIME

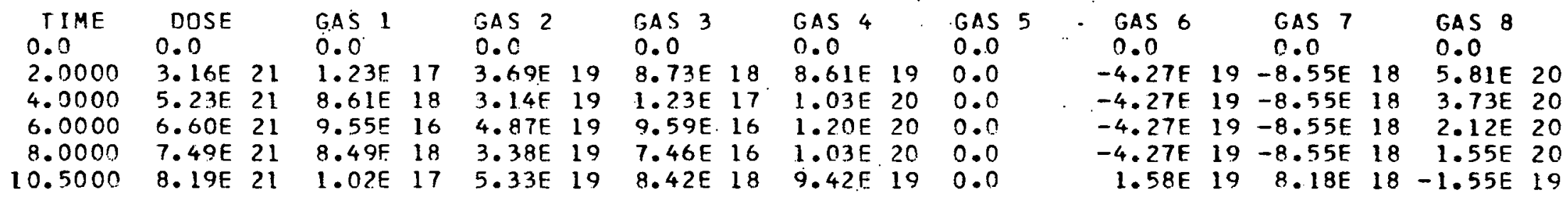

RAD

RADIOLYSIS DATA REDUCTION PROGRAM TEST

CHANGE IN MOLECULE POPULATION FROM ZERO TIME

$\begin{array}{ccccccc}\text { TIME } & \text { DOSE } & \text { GAS } & & \text { GAS } & 10 \\ 0.0 & 0.0 & & 0.0 & & 0.0 & \\ 2.0000 & 3.16 E & 21 & -7.40 E & 19 & 2.5 S E & 19 \\ 4.0000 & 5.23 E & 21 & -1.01 E & 20 & 2.58 E & 19 \\ 6.0000 & 6.60 E & 21 & -1.27 E & 20 & 3.42 E & 19 \\ 8.0000 & 7.49 E & 21 & -1.44 E & 20 & 4.26 E & 19 \\ 10.5000 & 8.19 E & 21 & -1.61 E & 20 & 4.25 E & 19\end{array}$




\section{Program Listing}

C RADF 060166

DIMENSION TITLE (16), DOSE (100), TIME(100), SUMSAM(16), GASVP(16) DIMENSION LABLI(16), LABL2(16), GASMOL $(100,16)$, AVOGAS $(100,16)$, 1DELMCL $(100,16)$

\section{FORMAT $(4 X, 16 A 4)$}

2101 FORMAT(4HIRAD)

INPT $=1$

LIST $=3$

READ(INPT, 2110$)$ NJOB

2110 FORMAT $(4 X$, I 4$)$

DO $110 \mathrm{JOB}=1, \mathrm{NJOB}$

WR ITE (LIST, 2101 )

21 READIINPT, 2010) TITLE

READ(INPT, 2011$) L, K, V, A Z R O, E B A R, F L A M$

2011 FORMAT $(10 X, 214,3 F 12,6, E 10.3)$

TEN $17=10.0 * \div 17$

AVNR $=6.023 \%$ TENI 7

$A M P L=1332.0 * T E N 17 * A Z R O * E B A R / F L A M$

DO $31 I=1, K$
SUMSAM $(I)=0.0$

DO $45 \mathrm{~J}=1, \mathrm{~L}$

READ (INPT, 2013 ) P, T, SV,TIME (J)

2013 FORMAT $(12 \times, 4 \mathrm{~F} 10.4)$

$A L L=(P * V) /(0.08205 * 76.0 *(T+273.16))$

I F (EBAR) $110,35,36$

$35 \operatorname{DOSE}(\mathrm{J})=\operatorname{FLAM} * \operatorname{TIME}(\mathrm{J})$

GO TO 37

$36 \operatorname{DDSE}(J)=A M P L \div(1.0-\operatorname{EXP}(-F L A M: T \cdot I M E(J)))$

$37 \quad S B Y V=S V / V$

DO $45 \mathrm{I}=1, \mathrm{~K}$

2014 FORMATI $1,2 X, 2 A 4, F 8.4)$

GASMOL ( J,I ) = ALL*GASVP(I)

$\operatorname{IF}(\mathrm{J}-1) \quad 43,43,42$

$42 \operatorname{SUMSAM}(I)=\operatorname{SUMSAM}(I)+\operatorname{SBYV*GASMOL}(\mathrm{J}, \mathrm{I})$

GASMOL $(\mathrm{J}, I)$ - CASMOL $(\mathrm{J}, I)$ + SUMSAM(I)

$43 \quad \operatorname{AVOGAS}(\mathrm{J}, \mathrm{I})=\operatorname{AVNR} * G A S M O L(\mathrm{~J}, \mathrm{I})$

$45 \operatorname{DELMCL}(\mathrm{J}, I)=\operatorname{AVOGAS}(\mathrm{J}, I)-\operatorname{AVOGAS}(1, I)$

$I 1=1$

I $F(K-8) \quad 50,50,55$

$50 \quad M K=K$

GO TO 60

$55 \quad M K=8$

60 WRITE(LIST, 2010)TITLE

WRITE (L IST, 2015)

2015 FORMAT (4OHOMICROMOLES OF GASES IN REACTION MIXTURE)

WRITE(LIST, 2016) (LABL1(I), LABL2(I), I = I 1, MK)

2016 FORMAT(2IHO TIME DOSE , 8(2X,2A4)) 


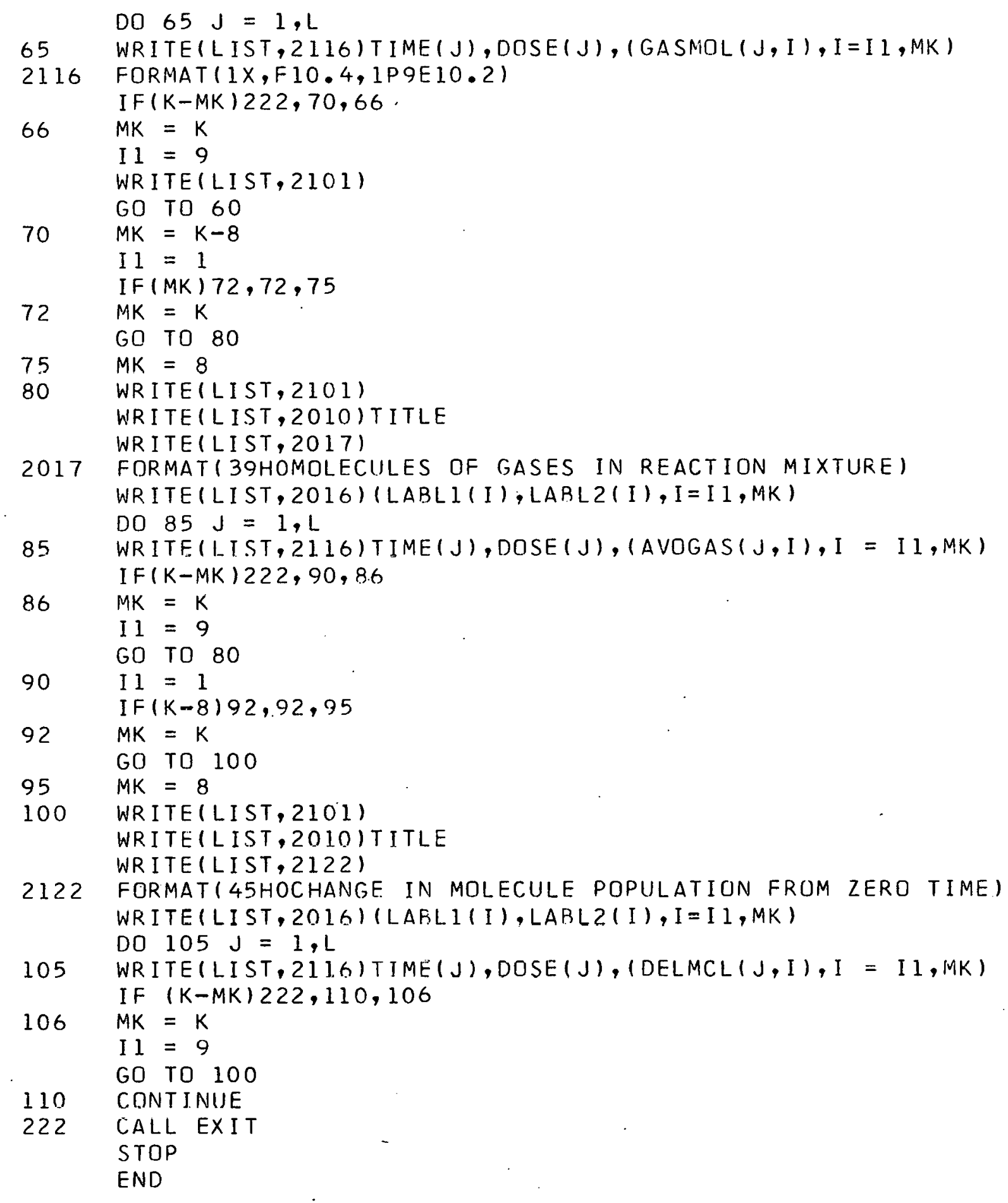

